\title{
下䫟関節突起骨折の予後に関する研究
}

\author{
岡達 - 金田敏郎 - 高橋彰 - 日比五郎 - 長山勝 \\ 岡本善博・湊文夫・田口望・杉浦憲治
}

\section{Studies on the prognosis of condylar fracture of the mandible}

\author{
Tatsu OKa - Toshiro Kaneda - Akira Takahashi \\ Goro Hibi - Masaru Nagayama - Yoshihiro OKamoto \\ Fumio Minato $\cdot$ Nozomu Taguchi $\cdot$ Kenji Sugiura
}

は じめに

下顎骨折のらち, 下顎関節突起骨折は多くの場合, 介 達性骨折であることからその発症機序に興味がもたれる が，臨床面においてはなお解明すべき 2,3 の問題を残 している. その第一点としては治療後に起こりうる後遗 症の病態究明, 第二に各種療法の予後成績検討, 以上の 二点が挙げられよう.

本症の後遣症は従来いわゆる post condylar fracture syndrome と総括されているが，しかしその病態は必ず しも明確ではない，とくに関節運動障害は本症の予後判 定に大きな point として用いられているにもかかわら ず詳細な検討は十分ではない，また受傷年柃，症型，療 法などの諸因子と後遗症発現との関連は適確なる療法選 択上で解明を要する問題であり, 多㑇度からの検索がま たれていると考えられる.

以上の観点から自家入院32症例について以下のごとき 臨床的ならびにX線学的研究を行ったので概要を報告す る.

\section{研究 方 法}

\section{1. 観察対象}

名大医学部口腔外科㧍よび名古屋第二赤十字病院歯科 口腔外科に入院加療した下顎関節突起骨折症例のらち, 加療後 1 カ年以上を経過した 32 症例である.

\section{2. 観察方法}

（1） 32症例を MacLennan 法1"に基き症型分類を独 自に行った上，種々なる観点から臨床統計的微察を加え た.

（2）損傷部位における残遣症状存否について自，他

名古屋大学医学部口腔外科学教室 (主任: 岡 達教授)

Department of Oral Surgery, Nagoya University, School of Medicine (Chief : Prof. Tatsu Oka)

受付 : 昭和51年10月 4 日
覚的症状の精查ならびに開口域，側方運動域の計測を行 った.

（3）顎関節の形態，頭の位置および動態を知る目的 から H jortsjö 法に準処, 後述の方法によりX線学的計 測を行った.

（4）本症患者の罘運動 pattern を知る目的から切歯 部限界運動図を著者らの方法により撮影し正常 pattern と比較検討した。

\section{研 究 成 樍}

\section{1. 臨床統計的観察}

観察症例は32症例で同時期顔面骨折入院症例の $27.2 \%$ に相当する．また，これらを MacLennan 分類に準処

表 1 症型分類例数拉よび骨折病態

\begin{tabular}{|c|c|c|c|c|c|}
\hline \multirow{2}{*}{ 症 } & \multirow{2}{*}{ 型 } & \multirow{2}{*}{ 症 例 数 } & 関節突起 & \multirow{2}{*}{$\begin{array}{l}\text { 下顎他部 } \\
\text { 位重骨折 }\end{array}$} & \multirow{2}{*}{$\begin{array}{l}\text { 顔面骨折 } \\
\text { 合 併 }\end{array}$} \\
\hline & & & 单 独 & & \\
\hline & I & 1 & & & 1 \\
\hline & II & 8 & 1 & 6 & 1 \\
\hline & III & 9 & 1 & 6 & 2 \\
\hline & N & 14 & 2 & 9 & 3 \\
\hline & 計 & 32 & 4 & 21 & 7 \\
\hline
\end{tabular}

I 転位の認められない骨折

II 軽度の転位骨折

III転位骨折

N 脱臼骨折

し4 型に分類すると（表 1 ）に示すように軽症のＩ型は 1 例に過ぎず,転位の大なる II, N 型が過半数を占めた.

一方, 本症例について合併骨折をみると当該部骨折の みに留まる例は 4 例に過ぎす，他の 21 例は下㖽骨他部位 に合併骨折をみる重骨折例であった。このことは関節突 起部が介達骨折の好発部位との所見を改めて認識させる 一方, この部の治療が複雑化することを示すものである. 
表 2 全症例の予後成緽

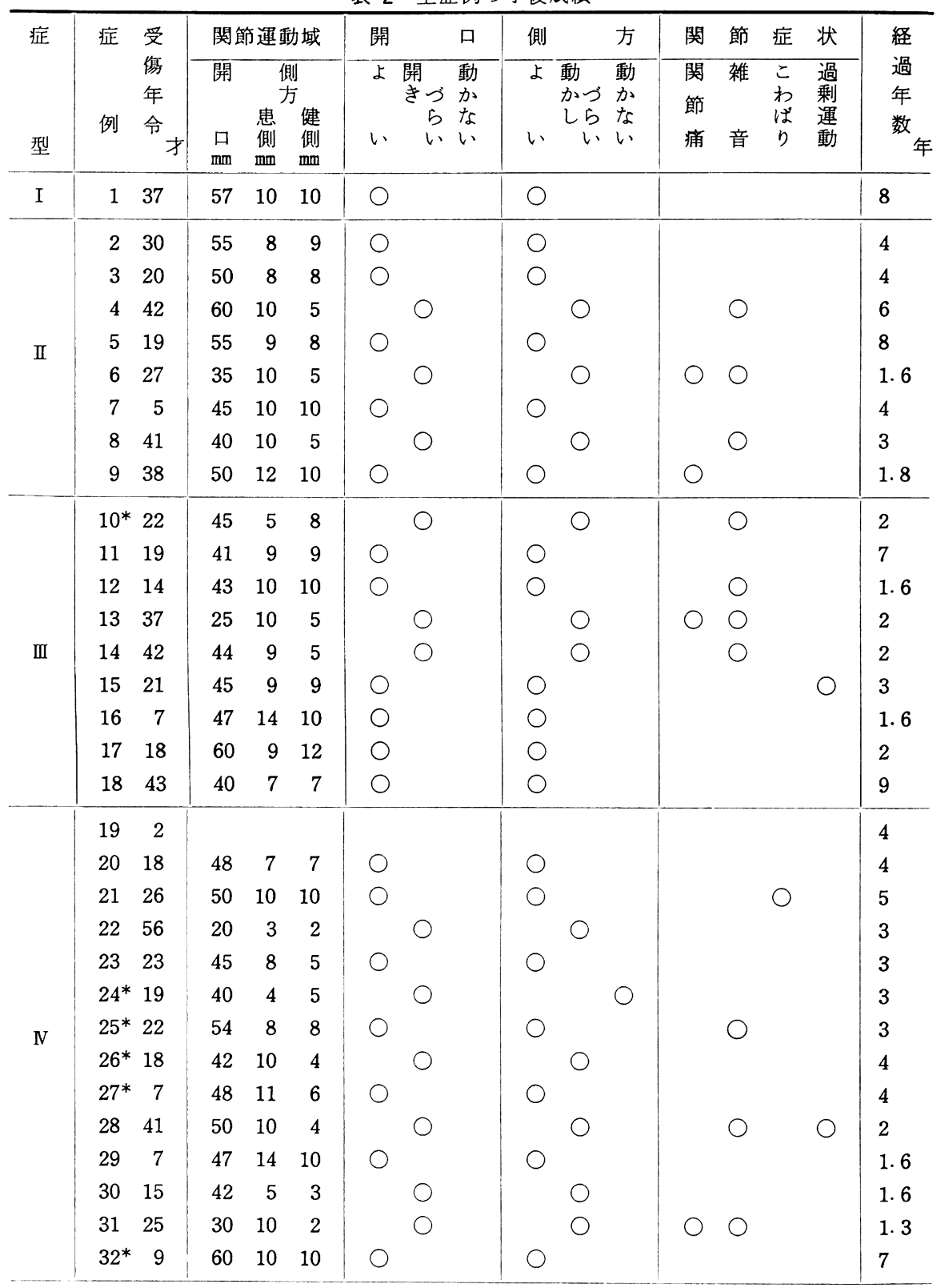

\section{2. 全症例の運動機能と関節症状}

全症例の子後成續を（表 2 ）に示す，運動域は当然個 人差があるので計測値と共に患者の主観による症状を調 查した．杉森 $\left.(1972)^{2}\right)$ の日本人開口域測定值を基準に 各年代に応して計測値をみると，31例中21例が概ね正常 值にあり，他の10例は開口域の狭小化を認めた。また計 測値と主観が合致したものは25例で他の 4 例は計測值正 常, 主観面では障害を感し，2 2 例は計測值は不良にもか
かわらず訴えのないものであったこれに対し，㑡方運 動域について特に左右非対称例は 10 例, 両側低下例 3 例 であるが，計測值と主観面は極めてょく一致する傾向を 認めたのは興味深い。

一方，関節症状を総括してみると，13症例にさまざま なる症状を認めた，そのらち，雑音は10例で最とも多く， 次いで関節痛, 過剩運動, こわばりの順であった。これ ら関節症状を訴えるもののうち 8 例は運動障害を有し, 
5例は概ね良好なる運動域を示するのであった。

過剩運動の発現は片側例の健側（反対側）に認められ た症状で，骨折側の前方滑走不全をあたかも補きならよ らに開口終末時相以後に前方へ移動することを認めた。

\section{3. 受賃年令と予後成綪}

従来の報告では受傷年齢とその予後との関係に論及し たものは少ない，少数例ではあるが，ここでは20藏未满 症例と30歳以上の壮年龄層に二分して倹討してみた。

（表 $3 \mathbf{A}, \mathbf{B}$ ）に示したように20歳未満症例のうち自覚的

表 $3 \mathbf{A}$ 受㑺年令と予後成績 20才末満症例

\begin{tabular}{|c|c|c|c|c|c|}
\hline $\begin{array}{l}\text { 症 } \\
\text { 型 }\end{array}$ & & $\begin{array}{l}\text { 受傷 } \\
\text { F令才 }\end{array}$ & $\begin{array}{l}\text { 経過 } \\
\text { 期間 年 }\end{array}$ & $\begin{array}{cc}\text { 開口 } & \text { 側方 } \\
\mathrm{mm} & \mathrm{mm}\end{array}$ & 節 \\
\hline \multirow{3}{*}{ II } & 3 & 20 & 4 & $50 \quad 8 \sim 8$ & ない \\
\hline & 5 & 19 & 8 & $55 \quad 8 \sim 9$ & な い \\
\hline & 7 & 5 & 4 & $45 \quad 10 \sim 10$ & ない \\
\hline \multirow{4}{*}{ III } & 11 & 19 & 7 & $41 \quad 9 \sim 9$ & \multirow{4}{*}{$\begin{aligned} & \text { な } \text { い } \\
& \text { 関節雑音（両側） } \\
& \text { な } \\
& \text { な } \\
& \text { な }\end{aligned}$} \\
\hline & 12 & 14 & 1.6 & $4310 \sim 10$ & \\
\hline & 16 & 7 & 1.6 & $47 \quad 14 \sim 10$ & \\
\hline & 17 & 18 & 2 & $9 \sim 12$ & \\
\hline \multirow{7}{*}{ N } & 20 & 18 & 4 & $48 \quad 7 \sim 7$ & ない \\
\hline & 24 & 19 & 3 & $40 \quad 4 \sim 5$ & 開口, 側方運動障害 \\
\hline & 26 & 18 & 4 & $4210 \sim 4$ & 開口, 側方運動障害 \\
\hline & 27 & 7 & 4 & $48 \quad 11 \sim 6$ & い \\
\hline & 29 & 7 & 1.6 & $47 \quad 14 \sim 10$ & な \\
\hline & 30 & 15 & 1.6 & $42 \quad 5 \sim 3$ & 開口, 側方運動障害 \\
\hline & 32 & 10 & 7 & $6010 \sim 10$ & な \\
\hline
\end{tabular}

表 3 B 受僨年令と予後成絿 30 才以上症例

\begin{tabular}{|c|c|c|c|c|c|c|}
\hline 型 & $\begin{array}{l}\text { 症 } \\
\text { 例 }\end{array}$ & $\begin{array}{l}\text { 受第 } \\
\text { 年 } \\
\text { 才 }\end{array}$ & $\begin{array}{r}\text { 経過 } \\
\text { 期間 } \\
\text { 年 }\end{array}$ & $\begin{array}{l}\text { 開 } \\
\text { 側 } \\
\text { mm }\end{array}$ & $\begin{array}{l}\text { 口 } \\
\text { 方 } \\
\text { mm }\end{array}$ & 症 \\
\hline \multirow{4}{*}{ II } & 2 & 30 & 4 & 55 & $8 \sim 9$ & \multirow{4}{*}{$\begin{array}{c}\text { な い } \\
\text { 開口, 側方運動障害, 雑音 } \\
\text { 開口, 側方運動障害. 雑音 } \\
\text { 関節痛 }\end{array}$} \\
\hline & 4 & 42 & 6 & 60 & $10 \sim 5$ & \\
\hline & 8 & 41 & 3 & 40 & $10 \sim 5$ & \\
\hline & 9 & 38 & 1.8 & 50 & $12 \sim 10$ & \\
\hline \multirow{3}{*}{ III } & 13 & 37 & 2 & 25 & $10 \sim 5$ & \multirow{3}{*}{$\begin{array}{c}\text { 開口, 側方運動障害, } \\
\text { 関節痛, 雑音 } \\
\text { 開口. 側方運動障害, 雑音 } \\
\text { な い }\end{array}$} \\
\hline & 14 & 42 & 2 & & $9 \sim 5$ & \\
\hline & 18 & 43 & 9 & & $7 \sim 7$ & \\
\hline \multirow{2}{*}{ N } & 22 & 56 & 3 & & $3 \sim 2$ & \multirow{2}{*}{$\begin{array}{c}\text { 開口, 側方運動障害 } \\
\text { 開口, 側方運動障害, } \\
\text { 雑音, 過剩運動 }\end{array}$} \\
\hline & 28 & 41 & 2 & & $10 \sim 4$ & \\
\hline
\end{tabular}

異常を有するものは14例中 4 例でその多くは軽度開口障 害, 側方運動狭窄とそれに由来する自覚的運動障害であ った.このらち 2 例は関節頭切除術 (condylectomy) を
受けたが，開口域としてはいずれも $40 \mathrm{~mm}$ 以上は確保 されており著明な開口制限ないし関節強直は諗めていな い.このため, 開口域のみの湘定で予後を判定すると良 坶と判断されて侧方運動狭窄とそれによる咀徱障害は大 きく見逃す可能性が強いことが考えられた。

つぎに30藏以上の壮年柃層症例をみると，9 例の推察 では運動制限を主体に関節痛，雑音，過㮃運動をみたも のが 9 例中 7 例に達し, 計測值, 自覚症状とも（よい） と判断されたものは 2 例に過ぎなかった。

このように20歳米满症状に比較して後遗症残遗率は著 明に高い結果をえた。この群について症例別の後遗症発 現状態をみると, 症型の軽重, 受傷後の経過期間等の影 響は意外に少なく関連は薄いことが明らかとなった，以 上，この異なる年㱓層でみられた成績の比較的明瞭な差 異については今後検討を要する問題を含むものである.

\section{4. 療法と予後}

本症に対する療法を保存的療法と観血的方法に分類, 予後を対比钼察した.なおここでは下顎他部位に存在 する合併骨折の処置方法の如何を問わず下䫇関節笑起部 に加えた療法により区分した.

表 $4 \mathrm{~A}$ 療法別予後成續

\begin{tabular}{l|r|rr|rr}
\hline \multirow{2}{*}{ 療 } & $\begin{array}{c}\text { 症 } \\
\text { 例 }\end{array}$ & \multicolumn{2}{|c|}{ 関節症状 } & \multicolumn{2}{|c|}{ 運動機能 } \\
\cline { 3 - 6 } & 数 & ない & ある & よい わるい & わる \\
\hline 保存的療法 & 27 & 16 & 10 & 18 & 8 \\
\hline 観血的療法 & 5 & & 5 & 1 & 4 \\
\hline
\end{tabular}

表 4B 手術症例の予後成績

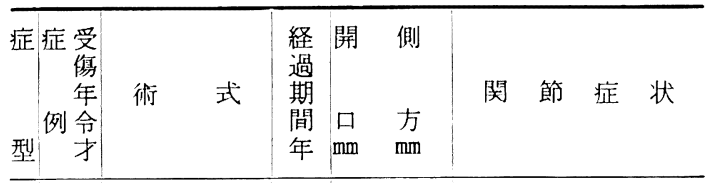
II 627 観血的整復術 $1.63510 \sim 5$ 開口, 側方運動障害

III 1520 镜血的整復術 $3 \quad 45 \quad 9 \sim 9$ 過剩運動

2419 関節頭切除術 $340 \quad 4 \sim 5$ 開口, 側方運動障害 IV 2618 関節頭切除術 $4 \quad 4010 \sim 4$ 開口, 側方運動障害 3125 関節頭切除術 $1.6302 \sim 10$ 開口, 側方運動障害 関節痛, 䧱音

成績は（表 $4 \mathbf{A}, \mathbf{B}$ ）に示すように 27 保存療法例では， なんらかの関節症状を有するものが10例であるのに対し 16例は特記すべき症状を認めなかったまた運動機能を 観察すると自，他覚的に「わるい」ものは 8 例に留まり 「よい」ものが 18 例に迋した。結局, 保存的療法では58 〜 66\%程度の症例がなんらの後遗症をも有しない良好な 予後をもつとの所見をえた。

これに対し手術症例の予後はよい結果はえられなかっ 
た.すなわち, open reduction 後に骨結禁を行った 2 例では，1例は僅かに過剩運動を健側に認めるのみで 概ね良好であったが，他の 1 例はなお十分な可動域を獲 得していない。 また， condylectomy 施行例では開口域 は $40 \mathrm{~mm}$ 程度を保有するものの側方運動域は著しく障 害される傾向を認めた．この例はすでに3〜4年の術後経 過期間を持っているが，この運動域はほとんど固定しそ
もほぼ満足すべき症例が多いのに対し， N 型は開口域で は軽症型に匹敵するものの側方運動域は狭小化する傾向 を認め，且型はその中間に所在することが判明した．次 に少数例ではあるが（表 6）に経年的観察による開口域 測定值の変動を示した. この成績では受傷後，約2〜3年 までは運動域の拡大が続き，その後に固定化する傾向が 認められた：しかし手術症例および壮年年齢層の一部症
间 口

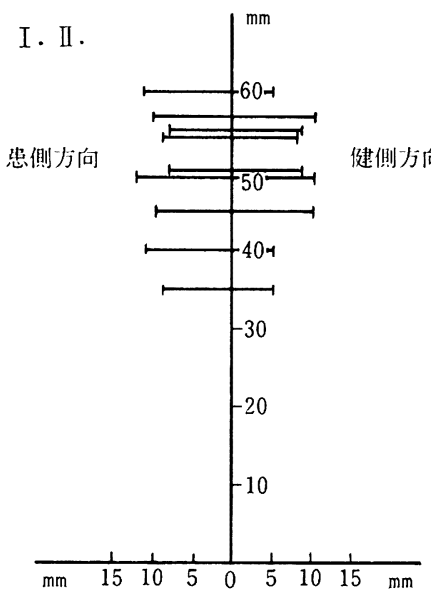

表 6 経過による開口域の変動

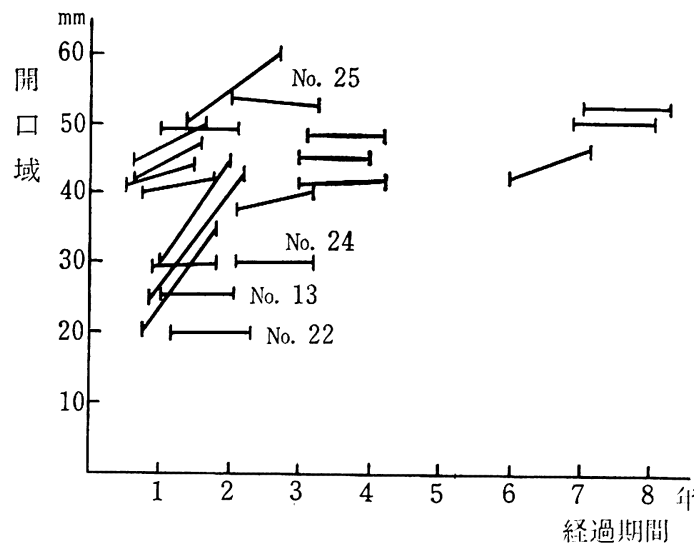

の後に症状改善は認めていない.

以上により療法別成續を小括すると少数例のため断定 はできないが保存療法は手術療法よりも後遗症の出現は 少なく，したがって手術療法の適応には慎重な検討を要 するとの印象をえた.

\section{5. 症型と開口, 側方運動域}

（表 5 ）は各症型における連動域を示している。これ によると柽症型の I , II 型群では開口域, 側方運動域と
表 5 各症型の運動域 開口
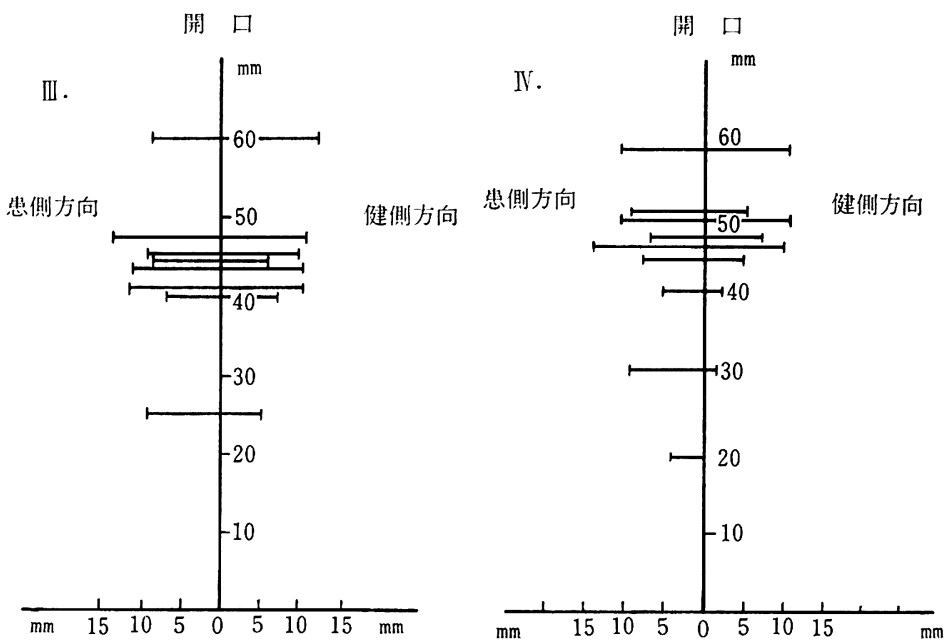

例では比較的早期から運動域が固定して变動を示さない 症例があった.

\section{6. その他の因子と予後}

受傷から当科受診までの期間長短による予後への影響 を検討した。これによると新鮮例（受傷後 2 週末満）で は約 $62 \%$ の症例が良好な経過を辿ったのに対し，陳旧例 （受傷後 2 週以上）では約 $50 \%$ がよい子後を示し，結局 新鮮例がやや成綨良㶩と考えられるがその差は明瞭でな くむしろ年踚, 療法による相異が判然としていた.

また，片側，雨側別の觀察では前述事項と同様に大差 のない結果がみられ，この点も明瞭なるのとは断言でき なかった。

\section{7. $\mathbf{X}$ 線学的計測}

本症例について開口時における関節頭の運動様相なら びに中心咬合位の関節頭の䓨内位㯰を検索するため以下 のX線学的計测を行った。

1) 計測方法

Hjortsjö (1960) $)^{3)}$ の方法に準処した.すなわち, Hjortsjöは計測資料に当該部矢状断層写真を用いたか， ここでは顎関節近接側方写真を使用した，左右同一性は 最大開口時にみあら bite block を咬ませて確保した。 計測は（図 1）に示すように関節結節および関節頭（あ るいは関節頭相当部）の中心点, 関節頭〜角部の後縁を 通る接線とそれに平行で関節頭を通る線をそれぞれ設定 


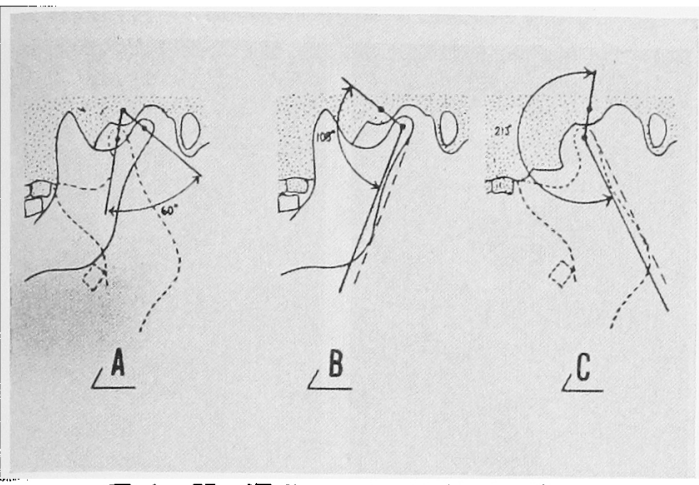

図 1 開口運動における関節頭X線計測 法（Hjortsjöによる）

した.この 2 点と線により

(1) 関節頭の関節窩内における中心咬合時の位置をみ るために $\angle \mathrm{B}$

(2) 開口運動における関節頭の位置をみるために $\angle A$

(3) 中心咬合位から開口位（最大）への移行時におけ る関節頭の傾きをみるために $\angle \mathrm{C}$

を測定した.なお，Hjortsjöの計測側に対比し，その 角度の大小について検討した。

2) 観察成績

測定しえた症例の計測結果を（表 7) に示すまず $\angle A は$ 患側が明らかに狭小化している所見をえた。この 表 $7 \mathrm{X}$ 線学的計測値

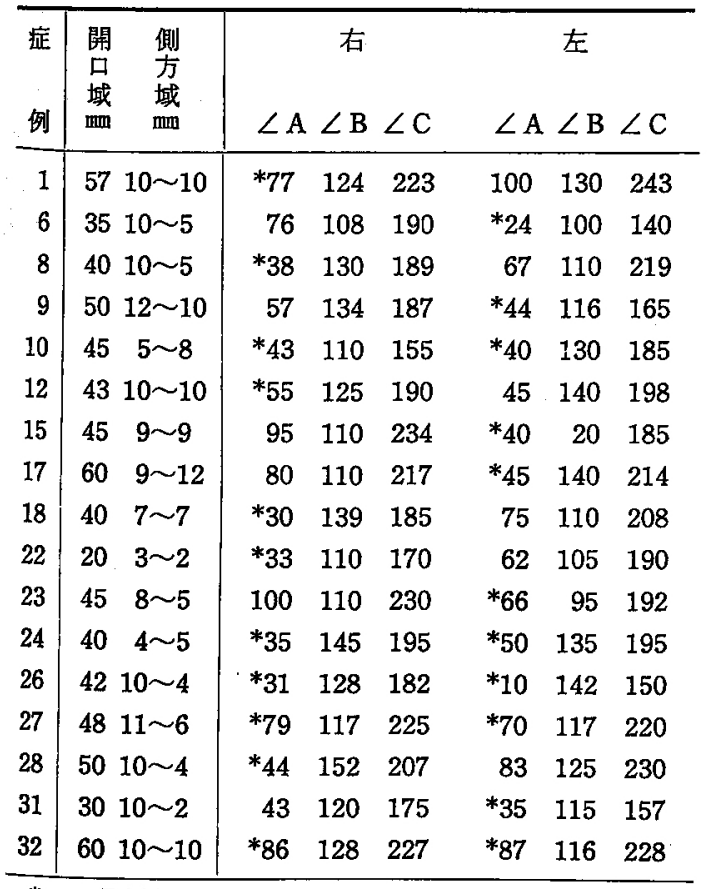

*......骨折側を示す
ことは患側の前方滑走度が健側に比較して低下している ことを示すものであるが，かかる所見を呈した症例は 13 例中 12 例に明らかですった。 また，これらの数值を Hjortsjö の $60^{\circ}$ K比較すると患側においてこの数檤よ り狭いるのは例中13例，広いるのは 4 例であり，概ね臨 休所見を缅付ける結果をえた。

つぎに 健側が 7 例，患側<健側 5 例であった. $\angle \mathrm{B}$ が広いこと は関節頭の窝内における位置がやや前方に在ることを示 するのといえる、したがって，この所見は関節頭が転位 したまま変位の状態で固定されたと考えることができる．

$\angle \mathrm{C}$ の計測值を単独にみると，13片側例の全例が患側 く健側の関係を示した. このことは患側の前方滑走運動 域が健側に比較して狭〉少ないことを示す所見であり， 開口域はもちろん側方運動障害の原因を構成するるのと 思われた. またこの計測では $\angle \mathrm{C}-\angle \mathrm{B}$ の数値が下顎 全体の開口運動に打ける動さと傾きを示すと判断して, 患健側を比較すると13骨折例 (片側) では健側が大です った.この榙討項目についてる患側の関節頭前方滑走域 が健側のそれより狭少化を来しているといら明瞭な所見 を壳た

\section{8. 切菌部限界運動图に上る検討}

さきに著者は関節運動機能検查の一法として, 切蒋部 限界運動記録法の応用に着目し, 以来正常人運動域の pattern を基盤に罘関節症などの関節疾患における運動 病態を検討してきた（岡19744)，19765)）

1) 検索方法

下顎前曾部に付けた splint の尖端に直径 $1 \mathrm{~mm}$ の電 球光源をつけ，開口，側方，前方等の任意の喕運動を絽 返えさせ，前・横・上の三方向からポラロイドカメラで 撮影，ての連動軌跡を pattern として補えた。これに より開口, 側方, 前方各運動域の筑囲 左右対称珄, 運 動の smooth さ，欠落運動相などを知ることができる.

\section{2）観察成續}

観察しえた症例のうち代表的症例の 2,3を学げる.

(1) 症例 $6: 27$ 歳男, 左側骨折, 開口域 $35 \mathrm{~mm}$, 側方 運動域 5〜10 mm で観血的療法例である. pattern は下 顎が最大開口時相に及ぶに従い左側へ下䫟正中が偏し， 側方運動も左>右の関係にあり右側への移行および右側 側方運動の範囲は左側に較べて明らかに狭い。したがっ て左側関節頭の前方滑走に著明な障害が推定される（図 2 A).

(2) 症例14:42歳女, 左側骨折, 保存療法例で開口域 $44 \mathrm{~mm}$, 側方運動域 $5 \sim 9 \mathrm{~mm}$. pattern の正面像は右側 の運動軌跡は明らかに欠落している.おおむねよい開口 域はえられているものの右側側方運動域は㹟小化し側方 連動に著明な支障の存在が示唆される．一方，側方をみ ると勃跡の走る範囲は狭く十分な前方，後方への下靧運 動に之しい所見である（図 $2 \mathbf{B}$ ）。 
第 6 例
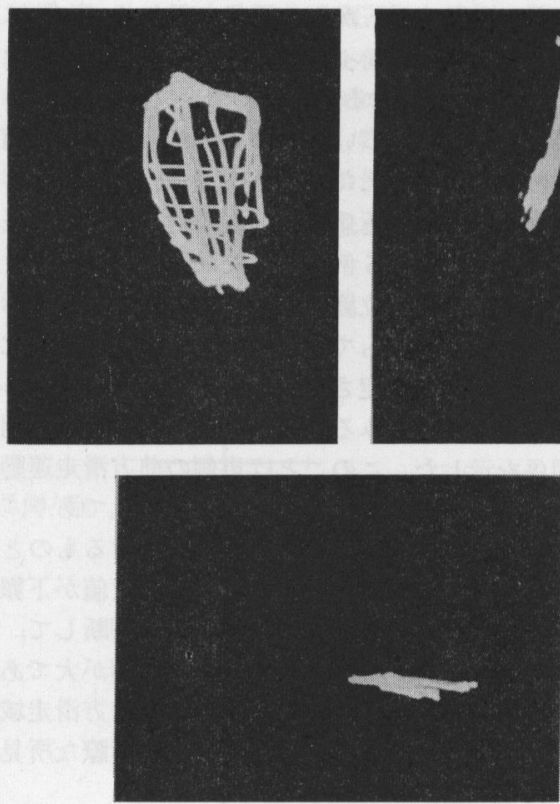

(A)
第 14 例
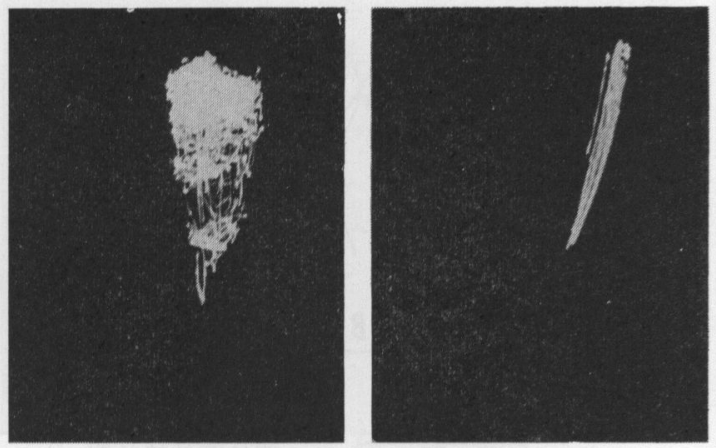

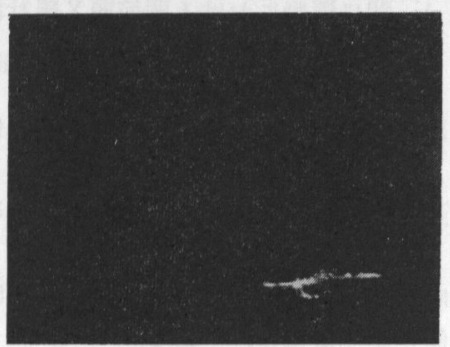

(B)

図 2 切雬部限界運動図

第 17 例

第 24 例
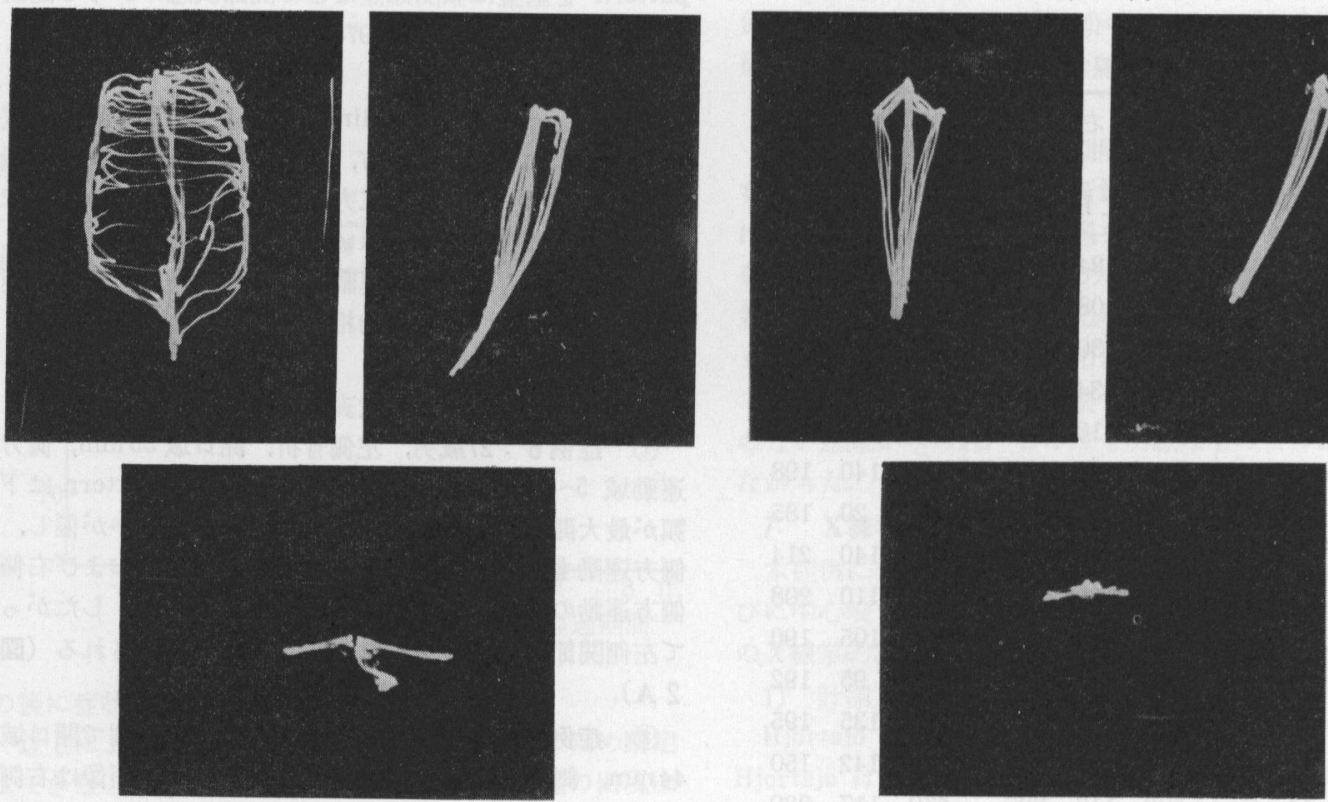

(A)

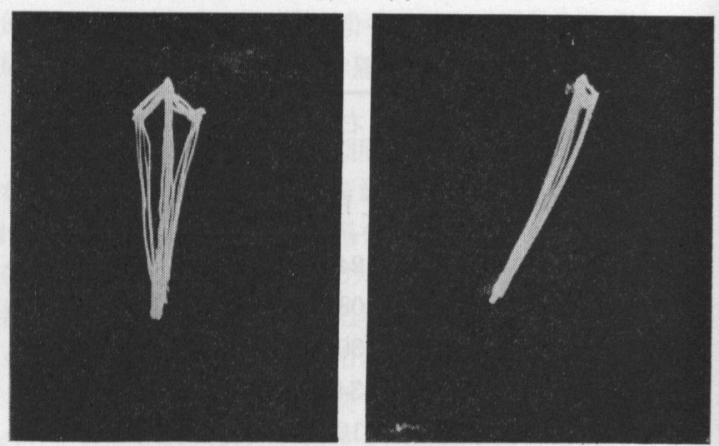

(B)

図 3 切歯部限界運動図

(3) 症例 $17: 18$ 歳男, 右側骨折, 保存療法. 開口域60 $\mathrm{mm}$, 側方運動域 9 12 mm. 正面の pattern はほぼ左 右対称性を示方一方, 開口側方運動域とも広い面積を有
している.この像の形態は正常な pattern にほとんど 近似しているほか側面像も幅広い運動域を認め, この面 も正常像に近い（図 $3 \mathbf{A}$ ). 
(4) 症例24:19歳男, 両側骨折, 関節頭切除例. 開口 域 $40 \mathrm{~mm}$, 側方運動域 $4 \sim 5 \mathrm{~mm}$, 図のごとく正面像では 概ねよい開口域を示すが pattern は pencil type を呈 し, 側方運動域の著明な狭索を認める.この所見は狭い 側方運動域の計測值と一致している. 側面像においても 幅の狭い, pattern であり, 関節頭相当部の前方, 後方 移動が強い支障により制限されていることを示す（図 3 B).

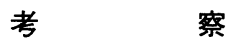

本症の後遺症として子測されるのはいうまでもなく関 節運動の障害存否が最とも重要な核心となろう.この場 合，関節頭部の損傷は脱臼合併のいかんを問わず関節軟 部構成体に対しても損傷を与える可能性が強い。したが って運動機能の障害は骨折以外に軟部損傷による二次的 継発的障害として成立する場合も想定される.この点か ら本症ではさまざまの関節症状をも合わせて観察すべき である.

運動機能の子後を評価するに当って，開口運動障害の 有無を主眼とするのは, 一つの方法であろらが顎運動を 構成するいま一つの機能として側方運動域の検討も無視 しえない要素であり, 開口運動域と同価の検索事項と考 えた.

本研究では関節運動の判定に際して, 運動域計測とい う客観面と患者の訴え, 感じなどの主観面を等価とした. これは開口域に良否については部測値と患者の主観とが 必ずしも一致しない点を考虑したことによる.

この研究では Hjortsjö のX線計測法に準拠して関節 頭の動態を計測する一方, 切蒾部限界運動図を応用追加 した. 本法は顎運動を巨視的または詳細に把握する目 的から三浦 $\left(1955^{6)}, 1956^{7)}\right)$, 佐久間 $(1959)^{8)}$, 根本 $(1962)^{9)}$, 大石 $(1963)^{10)}$ のすぐれた研究により発展した ものである.これを顎関節疾患の運動病態分析に応用す るに当っては，高木教授 $(1973)^{11)}$ の教示により任意の 顎運動のくりかえしによる軌跡の集積を困形としてとら え smooth さ, 運動度数による可動域の変動などをも観 察した.

成績について特記すべき点を挙げると，まず症型別の 後遺症発現率は予想されたごとく, 軽症群よりも $\mathrm{N}$ 群に 運動障害をみる傾向が多かった.この所見は脱臼ないし 骨転位の存否が以後の運動機能を含む後遺症発現に相当 なる影響をもつことを否定していない.

新鮮例, 陳旧例あるいは片側, 両側別など病像の差異 による成績の差については前者に関して黒井 (1972) ${ }^{12)}$, 後者は中富 $(1964)^{13)}$ によりそれぞれ差ありとの報告が あるが，本研究ではそれほど明確な結果はえられなかっ た.むしろ年齢, 療法別成績の相違に注目したい.

一方, 運動機能のらちいかなる運動が障害され易いか の点についてみると開口，側方が単独または合併してい
るが，計測值と患者主観的訴えがよく合致するのは側方 運動であった.これまで本症の予後判定には開口域のみ に主眼が括かれているが, 顎運動の重要な要素としての 側方運動の検索も開口と同じく重視すべきで開口，側方 ならびに関節症状の 3 点から評価するのが妥当と考える

受傷年齢と予後との関連は若年者ほど後遺症出現が少 ない所見をえた. かかる年龄差による予後検討について 詳細に論及した報告は少ないが，若年層に後遺症が少な い所見は注目すべき点である. その理由には潜在的な自 己整復力, 顎発育途上にある近傍組織との関係などが挙 げられよう。一般小児骨折における自己整復力について は，すでに泉田 $(1973)^{14)}$ が指摘し小児骨折の治療指針 上に反映させている。したがって，下顎骨折に扣いても 年路による治療法選択の検討がのぞまれてよい.

本疾患の療法については観血的あるいは保存的療法の いずれをとるか議論のある処であるが，観血的処置を施 して良好な成果を挙げたとの報告(太田1976) ${ }^{15)}$ もある. 少数われわれは少数例の経験なので断定はできないが, 保存的療法に比較して必ずしも良好な予後をもつとは考 え難い印象をえている.本例の手術適応は骨折部位, 転位 脱臼の程度などにより判断されるが, 術式の上で 1 )関節 包の損傷を回避できるか 2）小骨片(関節頭)を正しく整 復できるか 3 ）小骨片を十分に固定することができるか 等の点が予後に影響するとして重視すべきものと思われ る. 1 ）を重視するならば包下部の骨折すなわち頸部下 骨折だけが手術対象であり，2）は術中X線検査によら ねばならないが,それでも十分な整位はえ難く，3）は単 純な金属線骨結禁では外翼突筋の強い引張りに抗し難い などの今後検討を要する経験をえた。したがって単純な open reduction でも慎重な考慮を必要と考えている.

一方 condylectomy 施行例はいずれも著明な側方運 動障害が確認された. 本手術は脱臼骨片または転位骨片 が著明に顎運動を障害する時に適応する術式であるが, 神中 $(1964)^{16)}$ が述べるごとく機能面にかなりの支障を 来たすことを予測せねばなるまい。

X線計測法では関節頭の異常な運動域狭小化を意味す る計測值をえたままた，中心咬合位に括ける関節窩内の 頭位置は健側に比較してやや前方に位置する所見をえた. これらの結果は運動域の異常值ならびに自覚的症状を論 拠づるものと考えられる.また，このことからこの計 測法は顎関節の運動をX線学的に検索する方法として価 值あることを認めるものである.

本症の場合, 顎運動に関与する器官, 組織のなかで損 傷をうけた部位は顎関節部に限局していると推測される. したがって, 切歯部限界運動図も概ね関節部の病態を忠 実に反映している筈である，この研究に応用したわれわ れの方法は運動域のほか, 運動の smooth 性, 左右の対 称性などを総合的に観察しらる点で予後判定に有用であ った. 一部症例にみられた側方運動の狭小化, 運動範囲 
の一部欠落像, 円滑を欠く運動軌跡などは計測值, 臨床 症状をよく反映するものであった.

$$
\text { むす ひ }
$$

われわれは下顎関節突起骨折の治療後 1 カ年以上を経 過した32自家入院症例について，その予後を観察した結 果, 次の結論をえた.

1. 本症の後遣症としては開口域と侧方運動域の狭小 化と雑音, 関節痛, 過剰運動症が主体をなす。

2. 関節運動機能の評価判定では開口域と側方運動域 を同価の要素とするべきである.

3. 受傷年跉と子後との関係では若年者ほど後遺症出 現の傾向は少ないことかららかがた.

4. 観血療法のうち, open reduction は適応症, 固 定法に十分考虑の余地があり, condylectomy は側方運 動域障害が出現する可能性がある. 総合的に保存療法が 傮るとの印象をえた.

5. 本症の運動域検索法としてはX線関節頭動態計測 法 (Hjortsjö) ならびに切雪部限界運動描記法が有用で ある。

$$
\text { 文献 }
$$

1) MacLennan, W. D. . Consideration of 180 case of typical fractures of mandibular condylar process. Brit J Plast Surg 1952.

2）杉森孝志：顎関節の hypermobility（過動性）に 関する臨床的ならびにX線学的観察，日本人各年 代最大開口域と関連して。病誌 $39: 1591972$.
3) Hjortsjö, C. H.: Anatomie und Physiologie des Kiefergelenks, Fortschr. d. Kiefer-u, Gesichts-Chir, Bd. VI, Georg Thieme Verlag. Stuttgart, 1960, s 18.

4）岡 達: 顎関節の運動機能検査法として応用する ための切歯部限界運動記録法の検討. 口科誌23 : 4841974.

5）岡 達, 他：買関節疾患に対する切歯部限界運動 記録法の応用, 顎運動とそのメカニズム、日本歯 科評論社, 東京, 1976, 408面.

6）三浦不二夫：生体に打ける各種圧力の電気記録法 とその成績. お茶の水医学誌 $3: 5031955$.

7) 三浦不二夫：買運動直視装賸の試作. 日生理誌 $18: 310,1956$.

8）佐久間弘毅：マルチフラッシュ装置による有歯額 の前後および開閍運動の研究. 口病誌 $26: 1511$ 1959.

9) 根本一男: 有歯顎の下顎切歯点に拈ける三次元的 運動限界の研究. 補緅誌 $6: 11962$.

10) 大石司郎：アーム型運動分解器とコンデンサー法 による下顎運動の研究, 第 1 報. 口病誌 $29: 164$ 1963.

11) 高木健太郎：個人的教示による.

12) 黒井満：䫇関節突起部骨折に関する臨床的研究. 口科誌 $21: 8471972$.

13) 中富憲次郎：顎関節突起骨折の臨床的研究. 口科 誌 $13: 1321964$.

14）泉田重婎：小児骨折. 日整会誌 47 : 13151973.

15）太田舜：観血的療法による顎関節突起頸部骨折の 6 症例について。 日外誌 $22: 701976$.

16）神中正一：肩関節. 神中整形外科学, 南山堂, 東 京, [965, 531 頁. 